\title{
Some Observations on the Life-history of Anabaena Cycadeae.
}

\author{
BY
}

\author{
ETHEL ROSE SPRATT, B.Sc., A.K.C. \\ Demonstrator in Botany at King's College, London.
}

\section{With Plate XXXII.}

\begin{abstract}
MONG the members of the Cyanophyceae perhaps none are more interesting than those which are found endophytic in certain other plant structures. The best known examples of these are Anabaena Azollae, inhabiting the leaves of Azolla; Anabaena Cycadeae, living in the modified roots of Cycas; and the Nostoc sp. associated with the thallus of Anthoceros and Blasia. In each of these cases the region occupied by the Alga is an intercellular space. In Cycas this space is in the form of a zone between the cortical cells, just below the epidermis, known as the algal zone, which Bottomley has shown always contains living in it two kinds of nitrogenfixing Bacteria, Pseudomonas radicicola and Azotobacter, in addition to the Anabaena. Considering, therefore, the highly specialized habitat in which the organism is found, and the probable symbiotic relationship existing between the Anabaena and the two species of Bacteria, the life-history of this Alga provides a very interesting subject for investigation.
\end{abstract}

\section{MATERIAL AND Methods.}

The root tubercles of Cycas are found to retain their vitality for weeks, and even months, if they are wrapped in moist blotting-paper and kept in a tin box. This keeps them in a healthy condition for a surprising length of time, and by examining portions of the algal zone from time to time, the various stages constituting the life cycle of the Anabaena may be observed.

Several methods were employed to induce the organism to grow in an artificial medium, but with very varied success. The most promising medium was water containing some sap, obtained by crushing a few Cycas roots and tubercles. Solutions containing inorganic salts were not at all successful. To some of the former medium I \% agar-agar was added, the solution boiled and subsequently cooled, so that a solid medium was

[Annals of Botany, Vol. XXV. No. XCVIII. April, 19r.] 
produced such as Klebs and others have used in cultivating various Algae. Here, however, exceedingly slight growth of the Anabaena was obtained, although bacterial colonies appeared. Blotting-paper soaked in dilute sap from the tubercles, and kept moist in a Petri dish, was found to provide a suitable medium for the artificial culture of the Alga, small green patches of Anabaena appearing after a time in various parts of the blotting-paper. They appeared to lodge themselves in the pores of the substratum and there grow and divide. In the case of all the above media, several positions both with regard to light and temperature were tried, and the most favourable for the development of the organism appeared to be one illuminated by diffuse light, with a temperature of about $35^{\circ} \mathrm{C}$.

In view of the fact that during some period of its life-history this Anabaena must continue its existence in the soil around the Cycas roots in order that it may infect the newly formed tubercles, a kind of artificial soil, placed in a Petri dish and kept damp, was inoculated with some of the Alga. Here, however, arose a new difficulty, namely, the manipulation of such a medium for the examination of the growth therein. Further, as will be shown later, it is exceedingly improbable that the organism exists in the soil in its easily recognizable vegetative condition.

The various stages in the life cycle were repeatedly obtained directly from the nodules, kept for varying periods, as described above. In order to determine the connexion between the stages thus observed, a number of hanging-drop preparations were employed.

When studying the action of various stains and reagents on the organism, it was found most successful and convenient to use albuminized slides, and then allow the drop containing the Alga to dry on the slide slowly at the atmospheric temperature. With this method very little contraction of cells or their contents took place, and when dry, the organisms were adhering to the slide, so that any reagent could be readily applied for any length of time. When it was desired to use a fixative, a small quantity of $2 \%$ osmic acid was added to the drop containing the Alga. Flemming's fluid and Bouin's fixative have also been used with considerable success. The various stains and chemicals used, together with their reactions, will be described later, as they emphasize particular portions of the life cycle.

\section{Vegetative Structure.}

The species of Anabaena found in the Cycas tubercle (Pl.XXXII, Fig. I) is a typical member of that group, each filament having around it a sheath of highly transparent mucilage. The trichomes are more or less straight or circinnate, and heterocysts are very abundant. The vegetative cells are small spherical cells, slightly flattened at each end. Their contents are bluegreen in colour, usually very granular, but they may assume a homogeneous appearance. 
The cellular investments of the cyanophyceous cell are quite unique. They are, however, difficult to recognize in the unstained condition, hence Kuitzing and Borzi thought that the protoplast was bounded merely by a plasmic membrane inside the mucilaginous sheath. Gomont and Kirchner demonstrated the presence of a definite membrane in all cases, and Fritsch more recently gives a detailed account of the cellular investments, with which the following observations on Anabaena Cycadeae are in accordance.

The external mucilaginous sheath (Fig. 3, m.s.) is comparatively narrow, and remains unaffected by any stain used, except vesuvin, which renders it brown. It is, however, distinctly visible both in stained and unstained preparations as a highly transparent, refractive zone surrounding the cell. This mucilage ceases to be secreted by the heterocysts, consequently it is only found enveloping these in their early stages of development (Fig. 3).

Each protoplast, when fully formed, is typically provided with two investments. In very young filaments, however, there is only a colourless investment present, which becomes evident when the external mucilaginous sheath is stained brown by vesuvin (Fig. 4). It is convenient to call this membrane the inner investment, and in older cells between it and the mucilage there is a small cylindrical sheath known as the outer investment (Fig. 3,o.i.). The adjacent cells of a filament are separated by a transparent colourless band, the transverse septum (Fig. 3, t.s.), which has slightly concave lateral limits, and distinctly separates the outer investments of the two cells; the latter have well-defined lateral portions, but these are joined by much less readily discernible transverse membranes.

Gomont found that a $33 \%$ solution of chromic acid dissolved away the greater portion of the protoplasmic contents, leaving the cell membranes intact. This was indeed found to occur except in some very young vegetative cells where the definition had been somewhat lost. The cyanophyceous cell membrane is quite unlike that of any other Algae, apparently being of a very rudimentary type of development, and of a viscous mucilaginous nature, while it is capable of offering great resistance to oxidizing agents, and at the same time possessing remarkable elasticity, as shown by Brand's plasmolysis experiments. Kohl has demonstrated the presence of chitin, cellulose, and pectin in the membrane. The presence of the latter is clearly indicated by its absorbing Ehrlich's haematoxylin and remaining unaffected by chloriodide of zinc, and also iodine followed by dilute sulphuric acid. Iodine renders the outer investment dark brown, but the inner one remains clear and transparent.

In Anabaena Cycadeae the cytoplasm extends from the cell-wall to the central body, and although the peripheral layers contain the pigment and are undoubtedly the centre of assimilative activity, there does not appear to be any definite chromatophore present.

Many observers, amongst whom are Stockmeyer, Zukal, Zacharias, 
Marx, Massart, Fischer, and Palla, have failed to find any nuclear structure in the central body present in the cyanophyceous cell ; but Wille, Scott, and Zacharias in his later work, have shown it to be of a nuclear character. Hegler says that it consists of a faintly stainable ground substance in which is embedded a small quantity of chromatin, but it possesses no nuclear membrane or nucleolus. Wager and Kohl have confirmed his observations, and in Anabaena Cycadeae also there does not appear to be any true nuclear membrane or nucleolus. Occasionally, however, such forms as Figs. 5 and 6 (P1. XXXII) have been observed where a body somewhat resembling a nucleolus is present, and in Fig. 5 there almost appears to be a rudimentary membrane. Irregular forms similar to those described by Kohl have also been noticed (Figs. 6 and 7). The central body contains albuminous material, which takes up methyl green, gentian violet, carbol fuchsin, and to some extent haematoxylin. It is present as granules, which vary both in size and number (Figs. 5, 6, and 7). The vegetative cells contain from one to five, whilst in the spores they are typically more abundant (Fig. 7), but may apparently be collected into one large granule (Figs. 5 and 6). Kohl found pectin substances, and also some which assumed a blue-black colour when treated with chloriodide of zinc, present. In Anabaena Cycadeae the former are indicated by the blue colour produced with haematoxylin, but no visible effect was obtained with chloriodide of zinc, even after forty-eight hours' immersion in this fluid.

The chief product of photosynthesis is glycogen, which is indicated by the reddish brown colour produced in the peripheral cytoplasm by treatment with iodine in potassium iodide; the colour being removable by the solution of the glycogen in water, unless the material has been previously treated with alcohol. Oil is frequently present in the form of very minute drops in the heterocysts and spores, as shown by the black colour produced in the presence of osmic acid.

A number of very distinct granules are present in the cytoplasm, which represent reserve albuminous material, and have been called cyanophycin granules. Zukal described them as distinctly differentiated portions of the protoplasm, and Hieronymus found them to contain nitrogen and phosphorus. They certainly appear to grow during the life of the cell, being larger in old cells and spores. This, with their disappearance in nodules kept in somewhat unfavourable conditions, is quite in agreement with their being reserve food material. They are most effectively stained by prolonged treatment with an alcoholic solution of eosin, when they become deep red. They swell and eventually disappear in dilute acids or caustic potash, become deep brown with iodine in potassium iodide followed by sulphuric acid, and are unaffected by alcohol, xylol, ether, Millon's reagent, or chloriodide of zinc. These granules are very abundant in the vegetative cells and spores (Fig. 8). In young heterocysts the terminal granules, and 
in some cases a central granule, respond similarly, but the old heterocysts are completely unaffected.

\section{Vegetative Division.}

The first indication of a division in a vegetative cell is the appearance of an indentation near the middle of the lateral walls (Fig. 9, b). This constriction commences in the cell sheath, and extends to the inner investment. A very thin colourless area in the cell contents becomes visible, near the centre of the mother-cell (Fig. 9, c). Wager says the division of a cyanophyceous cell is brought about by the formation of a transverse septum, which grows inwards from the lateral walls, dividing the cytoplasm and nucleus into comparatively equal parts. Kohl describes a distinct polar separation of chromatic substances accompanied by the formation of a definite chromatic figure. Gardner, more recently, says that in the bluegreen Algae are exhibited a series of nuclear structures passing gradually from a scarcely differentiated form of nucleus in which direct division occurs to a complex form showing a primitive type of mitosis. The division of the chromatin may precede or accompany the ingrowth of the cell-wall. In Anabaena Cycadeae the central body is a simple structure which divides directly after the new wall has begun to form; then a colourless strip appears between the two central bodies, and gradually extends across the cell contents to meet the investment, thus developing into the intercellular colourless area (Fig. 9, $d$ ). The new cells separate, and the individual cylindrical sheath of each becomes evident (Fig. 9,e).

\section{Heterocysts.}

Heterocysts are always abundant, but particularly in old material and fully developed tubercles gathered in autumn. They vary somewhat in size, but are usually a little larger than the vegetative cells (Figs. 3, IO).

They are formed from vegetative cells, their contents gradually becoming paler and more homogeneous. A bright highly refractive granule then appears near one, and later both, of the end walls of the cell (Fig. IO). These are cyanophycin granules, and frequently an exactly similar granule appears in the adjacent cell, on the side nearest the heterocyst (Fig. IO). Thickening of the cell-wall begins in one or both of the end walls, and extends laterally until the whole wall is thickened (Fig. II); at the same time there is a chemical change, and the heterocyst walls exhibit definite cellulose reaction. The walls adjoining the vegetative cells develop two little lip-like prominences internally, one on either side of the pore (Fig. I2), which in old heterocysts may meet and form a plate across the pore. The granules disappear, the contents becoming colourless and contracting, but they remain attached to the wall in connexion with a vegetative cell until the 
heterocysts are detached (P1. XXXII, Fig. I3). This development is in harmony with that described by Fritsch for some other Anabaena sp., but differs somewhat from Brand's account of Nostoc commune and Tolypothrix sp., since he only mentions granules in connexion with fully formed heterocysts, and does not describe the transition from the lip-like thickenings to a plate.

Intercalary heterocysts usually occur singly, but in old filaments the vegetative cell on either side of a heterocyst may be thus differentiated, in which case the filament breaks and liberates the old one (Fig. I4). A dark green intercellular substance is sometimes excreted between the two adjacent cells (Fig. I 5, a), which assumes a flat, bi-concave shape, and loses its colour, while the two cells are transformed into heterocysts (Fig. I5, b); then the filament breaks at that point (Fig. I $5, c$ ). This phenomenon was observed in Anabaena obtained from old nodules, and also in hanging-drop cultures about a fortnight old. Brand describes a similar formation in connexion with the production of pseudo-branches and heterocysts in Tolypothrix and in Nostoc commune during the disjointing of heterocysts in old cultures. The heterocysts are stained bright green by methyl green, while only the central granules of the vegetative cells are thus affected. Their contents are also stained by aniline gentian violet, haematoxylin, fuchsin, and orange $G$.

Many suggestions have been put forward with regard to the functions of the heterocysts. Some of the earlier observers, amongst whom are Borzi, Hansgirg, and Kirchner, regarded them as subserving vegetative reproduction, and in some cases, as described above, their formation is connected with the breaking up of a filament, and the consequent formation of hormogonia. Hieronymus and Hegler interpreted them as receptacles for the storage of reserve substances. Brand described the liberation of their contents as gonidia, capable of producing new filaments in Nostoc commune and microscopicum; he also ascribed to them a storage function, and considered their contents as replenishing the exhausted adjoining cells. Fritsch points out that their differentiation into terminal and intercalary, as well as their occurrence in numbers side by side, compel us to attribute to them some function other than that of limiting the filaments, although this may be part of their work. He also regards them as recipients of reserve food material, serving for its storage under certain conditions. The fact that in Anabaena they only occur after some vegetative cells, capable of assimilating food material, and producing structures suitable for storing the surplus organic material manufactured, have been formed, together with the variation in their cell contents at different periods, suggests that this is a probable function. If, however, these are the only functions, what is the meaning of detached heterocysts, which certainly occur under both natural and artificial conditions? Brand's observations on the germination of their contents hitherto stand isolated, but this would account for their occurrence detached, and would also be an important stage in the life-history of 
Anabaena. Examples of this have been seen repeatedly in heterocysts of Anabaena Cycadeae, and will be described in detail in a later paragraph.

\section{SPORES-THEIR Formation and Germination.}

Spore formation in several members of the Cyanophyceae has been described by Borzi and Fritsch. This method of reproduction occurs abundantly in Anabaena Cycadeae in the algal zone of the nodule, and also in hanging-drop cultures under favourable conditions.

In this species the sporogenous cells are distinguishable by their wellmarked lateral walls. They usually appear first in portions of the filament furthest from the heterocysts. Each protoplast is surrounded by a thin strip of colourless substance which assumes a faint brown coloration with iodine, and is continuous with the similarly staining intercellular substance separating adjacent cells. This constitutes the actual cell membrane, the inner investment (Fig. I6,i.i.), and is bounded laterally by the cell sheath (Fig. I6, o. i.), which may be a specialized inner portion of the mucilaginous envelope (Fig. 16, m.s.), and becomes more markedly defined as the spores develop and the necessity for a firm outer covering arises. The transverse limits of the cell sheath gradually become more distinct, and the cells move further apart. Eventually the sheath closes round the open ends, enveloping as it does so a portion of the intercellular septum (Fig. I6). The mature spore thus has a complete exospore and endospore (Fig. I6, ex. en.). The remaining portion of the intercellular septum swells and separates the spores, which in this species are very similar in size and shape to the heterocysts.

The mature spores may rest, but they are also capable of germinating immediately under suitable conditions. A large number of germinating spores were examined in hanging-drop cultures, where the process could be watched in situ in the filaments for any length of time.

There appear to be four main types of germination. The most common is that in which the contents are slowly protruded through a pore in the spore wall (Fig. I 7). The contents contract, and a colourless papilla appears at one side (Fig. I $7, b$ ), which advances to the inner investment (Fig. $17, c$ ) and then pushes this membrane out in front of the escaping protoplast, probably to protect the latter as it passes through the exospore, during which passage it is distinctly compressed (Fig. I $7, d$ and $e$ ). The liberated protoplast is immediately followed by mucilage, which caused its liberation, and envelops it before a distinctly differentiated membrane appears (Fig. I $7, f$ ).

The second type of germination is that in which a portion of the spore membrane is split off (Figs. I 8 and 19). The lid so formed may be pushed out in front of the exuding mucilage (Fig. $18, a$ and $b$ ), or it may remain 
attached at one side to the rest of the spore wall (Pl. XXXII, Fig. I9). Another variation is caused by the contents germinating in situ in the portion of the spore wall (Fig. I9).

The third type is exhibited in those cases in which the exospore and possibly also the endospore become mucilaginous (Fig. 20), and the protoplast divides in its original position in the filament.

These three types agree with those described by Fritsch for Anabaena sp., whilst the fourth is in accordance with Borzi's observations. In this case the contents divide by a delicate wall into two initial cells of the filament (Fig. 2I, a). After this the membrane splits (Fig. 2I, $b$ ), and then the cells can expand and continue their growth (Fig. 2I, c).

\section{Formation OF GONIDIA.}

Reproductive bodies termed gonidia have long been known to occur in the Chamaesiphoneae, where they are well differentiated, and a number of observations suggest their formation in the Cyanophyceae. Brand describes their occurrence in Phormidium uncinatum, where they arise singly by the rejuvenescence of the whole or greater part of the cell contents. He also observed the liberation of these bodies from the heterocysts of Nostoc sp., and adds that similar structures may be developed from the vegetative cells in these species. Fritsch found in some of his old material some rather abnormally shaped cells amongst heterocysts and sporogenous filaments, which he says had their contents rounded off and contracted, and they had acquired a new membrane of their own inside that of the mother-cell. He also observed the liberation of these contents as a spherical gonidium, but saw no indication of division either before or after, and concluded that they were caused by the arrest of spore formation.

The formation of gonidia appears to play an important part in the life cycle of Anabaena Cycadeae, as was suggested above. It is interesting that it should be in this Alga, living in such a unique position, in symbiosis with a plant which has existed and flourished through a very long geological period, that we should have a confirmation of the phenomenon hitherto only observed by Brand, namely, the germination of the contents of the heterocysts for purposes of reproduction. This may be observed in material from old nodules and hanging-drop cultures, particularly in such as have been allowed to undergo partial desiccation, and then favourable conditions for further development have been restored.

Material obtained in this way is composed mainly of heterocysts and spores. The former have a third investment inside, round the contracted cell contents (Fig. 22), which are no longer homogeneous, but have resumed their granular appearance. The contents undergo direct division, so that two small granular bodies are apparent in the newly-formed membrane (Fig. 23), each of which divides directly again, and eventually a number of 
small spherical protoplasts are formed inside the original heterocyst walls (Fig. 25). These under certain conditions are liberated by the opening of one of the pores in the wall (Figs. 24, 25). The gonidia, when set free, have pale green contents, surrounded by an exceedingly delicate membrane, which soon becomes more definite, and the outward investment appears, also a very distinct granule lying near the centre of the cell, which no doubt represents the visible portion of the central body. Each of these small bodies is capable of resting for a time or germinating to form a small but typical Anabaena filament (Fig. 26), by division comparable to the process in a vegetative cell. Increase in size occurs both before and after division.

In view of the fact that the old material contained many spores, it is noteworthy that their contents on liberation are capable of differentiating directly into a heterocyst, which can then produce gonidia.

The formation of gonidia in Anabaena Cycadeae, besides supporting the proposition that heterocysts are the abortive relics of a method of reproduction once prevalent among the Cyanophyceae, also offers some solution to the problem: How does the Anabaena get into the Cycas tubercle? Since the Alga is not present in very young tubercles, it must at some time find an entrance, and must also be living in the medium around the roots, the soil. Means of entry appear to be afforded by the lenticels, which are present on the tubercles, through which the organism could readily enter as a small gonidium, and it is difficult to conceive how it could get through such a small opening in any other form. Anabaena Cycadeae is undoubtedly set free in the soil by the decay of old tubercles, in the form of spores and heterocysts, which under certain conditions give rise to gonidia, capable of forcing their way through the lenticels into the Cycas tubercle, where they encounter conditions favourable to their growth, and consequently there they flourish, producing vegetative cells, spores, and heterocysts.

Having entered the nodule, they confine their growth to a particular zone about four layers deep, and here, after their entrance and growth, the intercellular space, known as the algal zone, arises. It is very probable that conditions of aeration and illumination play an important part in the selection of this portion of the nodule, because in culture experiments where sections were employed the Anabaena spread to other regions besides the zone; here, however, conditions of illumination and aeration would be practically uniform throughout the section. The Anabaena, having chosen their home in the nodule, are very soon surrounded by the nitrogen-fixing bacteria, one of which, Azotobacter, entered the lenticels, like the Anabaena, whilst the other, Pseudomonas radicicola, was already established, and was indeed the primary cause of the tubercle formation. There is thus in the algal zone a wonderful symbiotic community consisting of an organism 
capable of obtaining its energy from the sun and manufacturing carbohydrate food material, not only for its own wants, but also sufficient to supply the source of energy to the Bacteria, which in their turn supply the nitrogenous material available to the Alga ; and all three find a habitat in the Gymnospermous plant, which undoubtedly benefits in its turn from the products of the metabolic activities of these organisms.

In conclusion, my most sincere thanks and gratitude are due to Professor W. B. Bottomley for his kindness and advice during the progress of the work, and to Dr. Fritsch for many helpful suggestions.

\section{SUMMARY.}

I. Anabaena Cycadeae is a typical Anabaena.

2. Each mature cell has two investments, an inner and outer, in addition to the external mucilaginous sheath.

3. The chlorophyll and phycocyanin are lodged in the peripheral cytoplasm, no definitely organized chromatophore being present. division.

4. The central body is a simple structure only capable of direct

5. The chief product of assimilation is glycogen.

6. Cyanophycin granules are very abundant.

7. In the vegetative division the ingrowth of the lateral walls is accompanied by direct division.

8. Terminal and intercalary heterocysts are formed from vegetative cells. They may become detached, and appear to have three functions :-

a. To limit the filaments-vegetative reproduction.

$b$. For storage of reserve food material.

c. Reproduction by formation of gonidia.

9. Spores are formed. The exospore and endospore are the fully developed cell sheath and inner investment respectively.

10. There are four types of spore germination:-

a. The contents are protruded through a pore in the spore membrane.

b. The spore membrane is ruptured.

c. The spore membrane becomes mucilaginous.

$d$. The contents divide before escaping from the spore wall.

I I. Gonidia are formed by the rejuvenescence and subsequent division of the contents of the heterocysts. A distinct membrane appears inside the walls of the heterocyst. A number of spherical gonidia are formed, each of which is capable of dividing to form a new Anabaena filament.

12. Anabaena Cycadeae maintains its existence in the soil in the form of heterocysts and spores, which develop into gonidia, and these enter the Cycas tubercles through the lenticels. 


\title{
BIBLIOGRAPHY.
}

Borzi : Note alla morfologia e biologia delle Alghe ficochromacee. Nuovo giom. botan. ital., vol. $x, 1878$, p. 236 .

Bottomley, W. B. : Some Effects of Nitrogen-fixing Bacteria on the Growth of Non-leguminous Plants. Proc. Roy. Soc., B., vol. lxxxi, I909, p. 287.

BRAND, F. : Bemerkungen über Grenzzellen und über spontanrothe Inhaltskörper der Cyanophyceen. Ber. Deut. Bot. Ges., Bd. xix, I90I.

: Morphologisch-physiologische Betrachtungen über Cyanophyceen. Beihefte z. Botan. Centralbl., Bd. xv, I903, Heft I.

- : Über das osmotische Verhalten der Cyanophyceenzelle. Ber. Deut. Bot. Ges., Bd. xxi, I $9 \circ 3$, Heft 6, p. 302 .

Fritsch, F. E. : I. Studies on Cyanophyceae. New Phytol., vol. iii, 1904, No. 4.

: II. Structure of the Investment and Spore Development in some Cyanophyceae. Beihefte z. Botan. Centralbl., Bd. xviii, 1905.

: III. Some Points in the Reproduction of Anabaena. New Phytol., vol. iii, I904, No. 9 .

Gardner, N. L.: Cytological Studies in Cyanophyceae. Univ. of California Public., Botany, vol. ii, 1906 .

Gomont : Recherches sur les enveloppes cellulaires des Nostocacées filamenteuses. Bull. Soc. bot. de France, sér. 2, t. x, I888, p. 204.

Kirchner : Schizophyceae. Engler u. Prantl, Die natürl. Pflanzenfam., Teil I, Abteil. I. a, I898.

KонL : Ueber die Organisation und Physiologie der Cyanophyceenzelle und die mitotische Teilung ihres Kernes. Gustav Fischer, Jena, 1903 .

KüTZING : Phycologia generalis. 1843 .

Lotsy, J. P. : Vorträge über botanische Stammesgeschichte. Erster Band, Gustav Fischer, Jena, I907.

Wager, H.: The Cell Structure of the Cyanophyceae. Proc. Roy. Soc. London, vol. lxxii, 1903, p. 4 ㅇ․

West, G. S. : A Treatise on British Freshwater Algae. Camb. Univ. Press, I904.

\section{EXPLANATION OF FIGURES IN PLATE XXXII.}

\author{
Illustrating Miss Spratt's paper on Anabaena Cycadeae.
}

Fig. I. Nodules of Cycas. Natural size.

Fig. 2. Portion of transverse section of nodule, showing algal zone; c., cork; o.c., outer cortex; A.Z., algal zone; i.c., inner cortex. $\times 500$.

Figs. $3^{-26}$ are magnified 2,200 times; m.s. denotes mucilaginous sheath; $0 . i$, outer investment; $i . i$. , inner investment; t.s., transverse septum; $H$., heterocyst; $y g . H$., young heterocyst ; $C . B$. , central body; g., granules; c.g., cyanophycin granules; v.c., vegetative cell ; T.H., terminal heterocyst ; I.H., intercalary heterocyst; $e x$., exospore ; $e n$. , endospore ; $p$. , papilla ; $m$. , mucilage ; sp.c., spore contents; sp.w., spore wall.

Fig. 3. Vegetative filament of Anabaena, showing the cellular investments.

Fig. 4. Very young vegetative filament.

Fig. 5. Vegetative cell, showing the central body with a semblance of a nucleolus and nuclear membrane.

Fig. 6. Typical vegetative cell, showing central body.

Fig. 7 . Vegetative filament, showing several different stages in the central body.

Fig. 8. Vegetative filament, showing the cyanophycin granules. 
Fig. 9. Vegetative cells in the process of division; $a=$ typical cell; $b=$ constriction in investment just appearing ; $c=$ division of central body ; $d=$ complete division of contents ; $e=$ membranes completed and two cells formed.

Fig. 10. Filament in which heterocysts are developing.

Fig. II. Filament containing terminal and intercalary heterocysts in which the thickening of the membranes has commenced.

Fig. I2. Filament in which the heterocysts have developed the lip-like prominences (l.), and the contents (c.c.) have contracted.

Fig. I3. Detached heterocyst.

Fig. I4. Development of a new heterocyst on either side of an old one which is consequently liberated.

Fig. I5. Development of new heterocysts following the excretion of intercellular substance (s.).

Fig. I6. Filament showing the development of spores $(s p$.).

Fig. I $7, a-f$. Series of stages illustrating the first type of spore germination.

Fig. 18, $a-c$. Series illustrating the second type of germination; $l$., piece of spore wall split off.

Fig. 19. Spore germinating. Piece of wall remains attached.

Fig. 20. Third type of germination.

Fig. 2 I, $a-c$. Fourth type; $w$., new membrane dividing spore contents ; $p$., pore.

Fig. 22. Heterocyst in first stage of gonidia formation; i.m., new internal membrane.

Fig. 23. Contents of heterocysts divided into two in $(a)$ and three in $(b)$.

Fig. 24. Three gonidia being liberated.

Fig. 25. Formation of number of gonidia $(g) ; a=$ beginning of their liberation; $b=$ liberation continued; $c=$ structure of gonidia visible.

Fig. 26. Gonidium germinated to form a small filament. 
Annals of Botany,
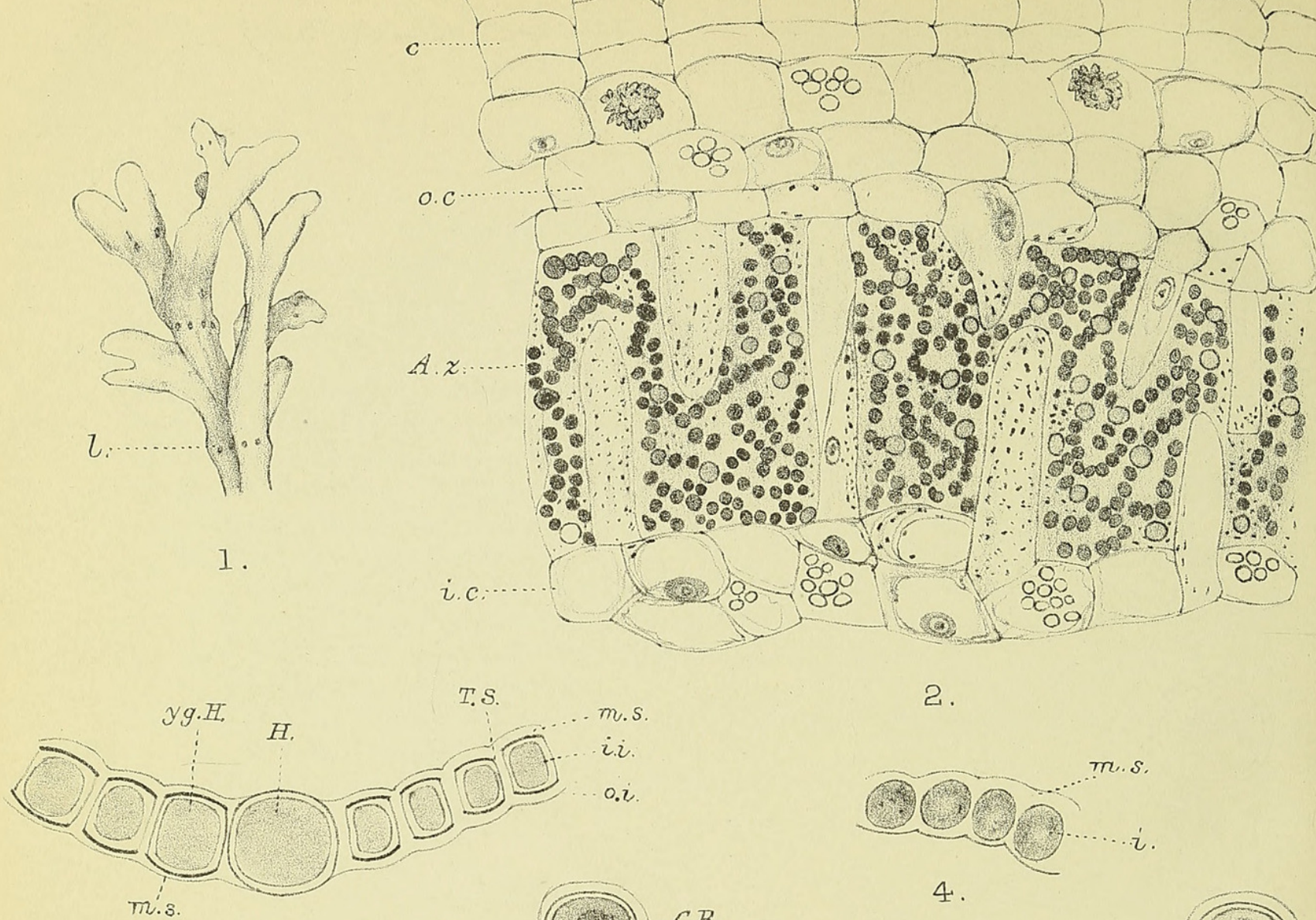

(c) C.B.
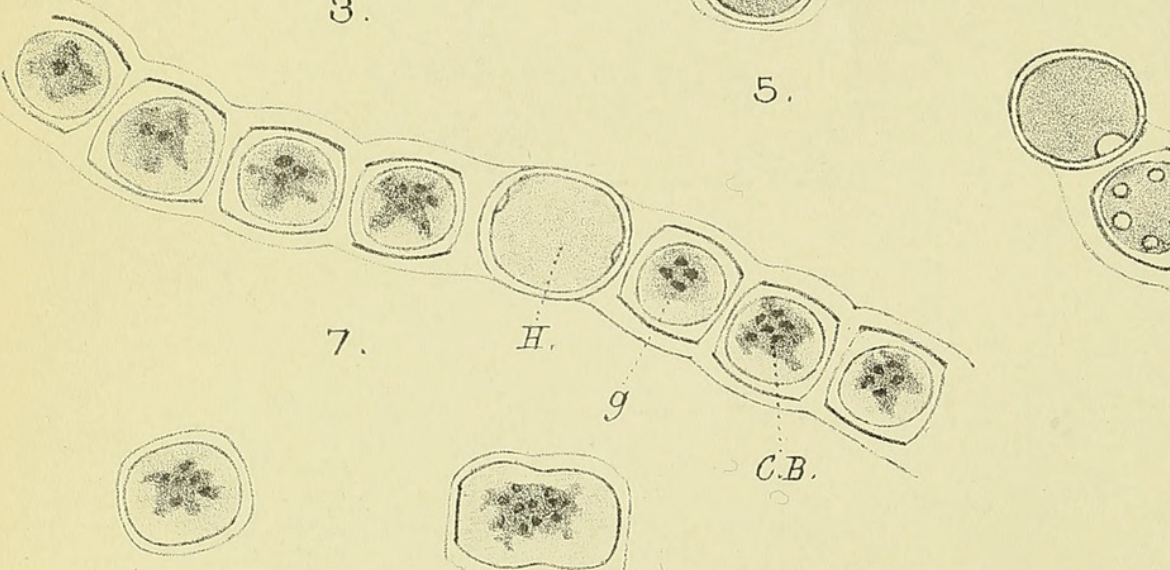

2.
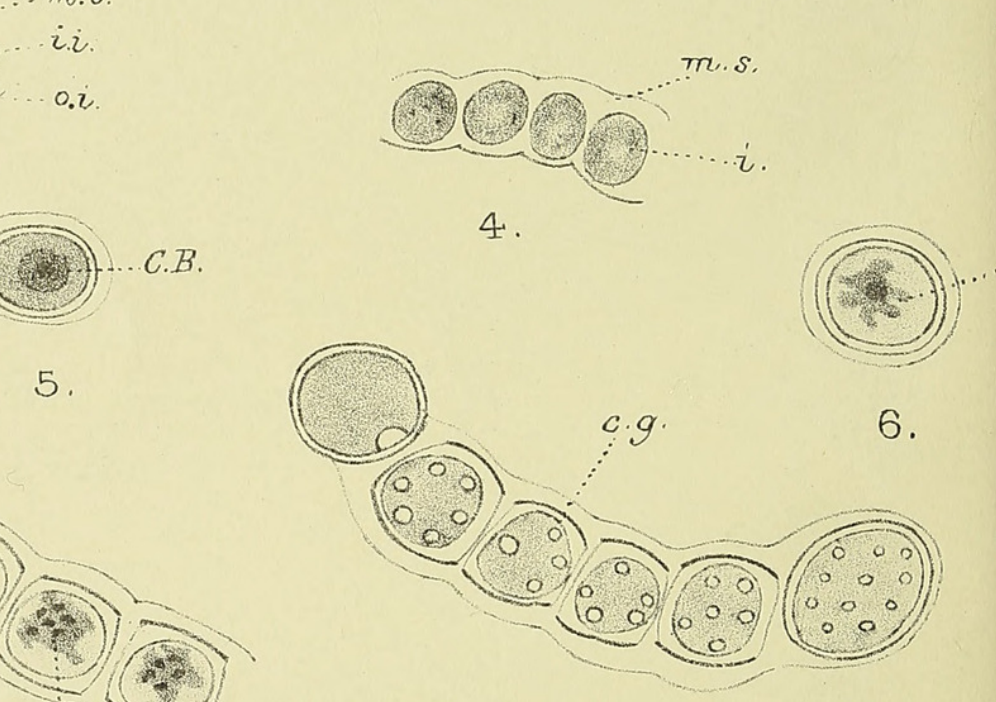

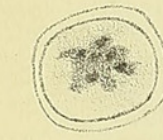

a

b

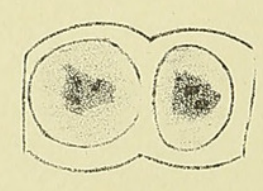

8.

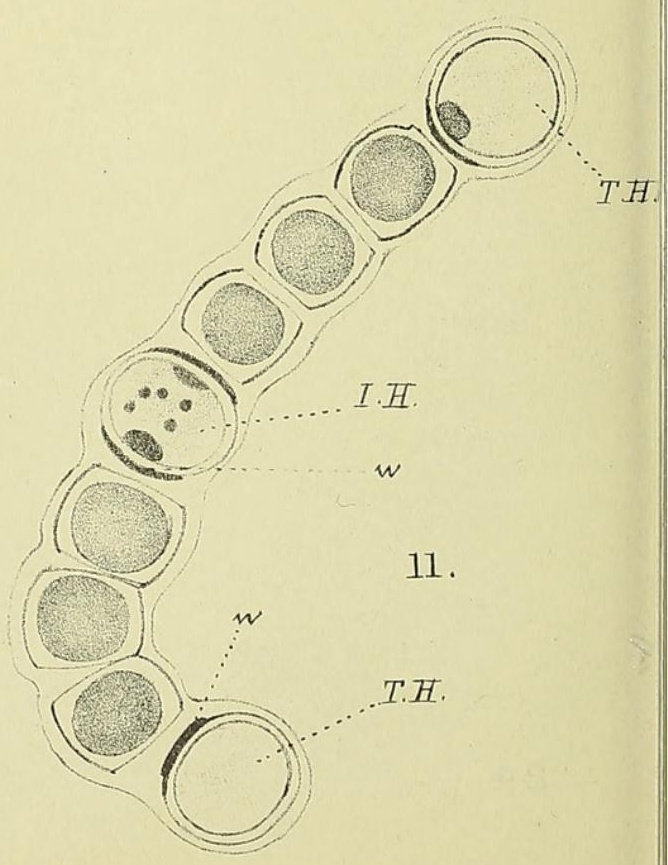


Vol.XXVI, PL. XXXII.
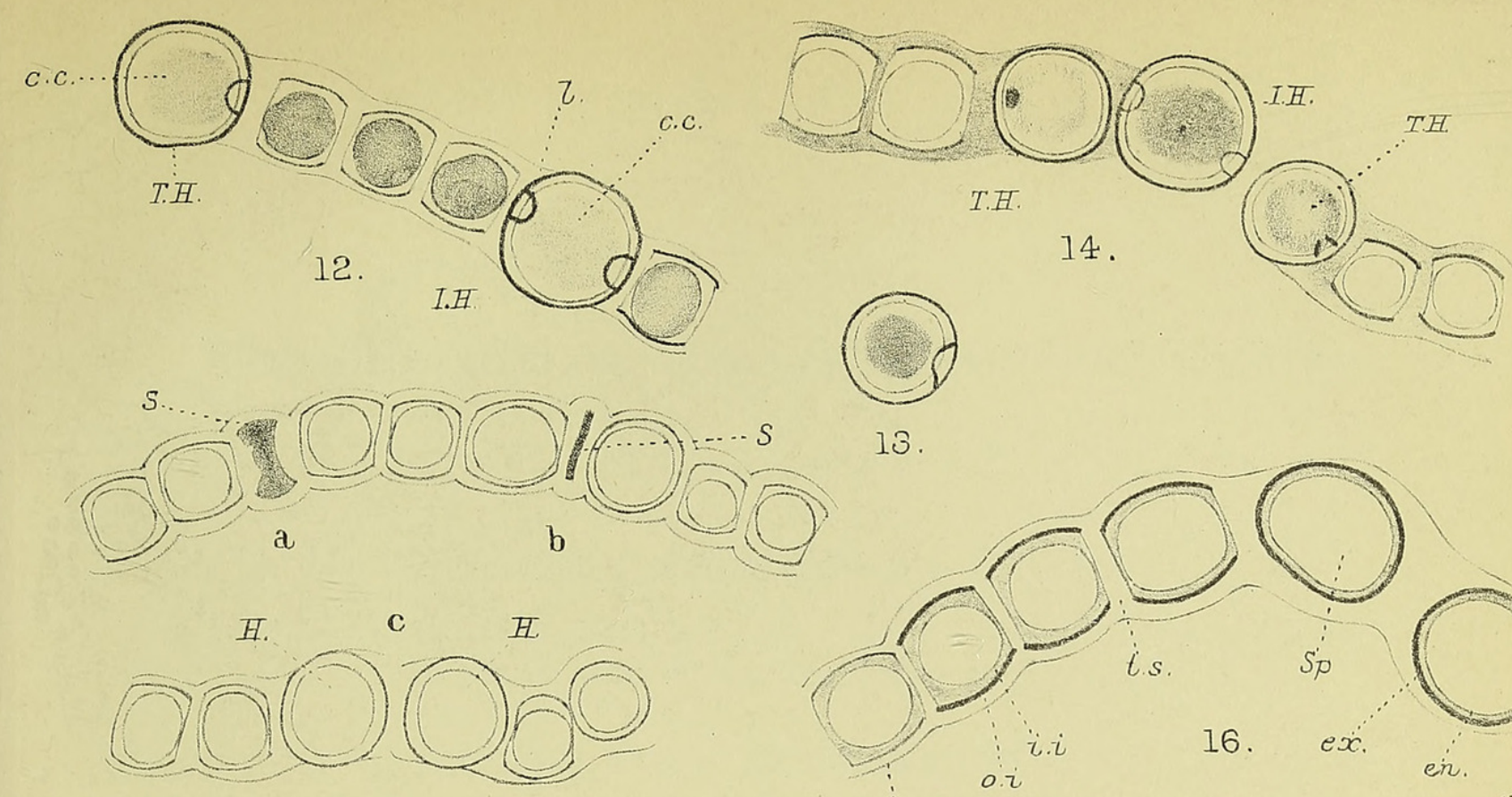

15.

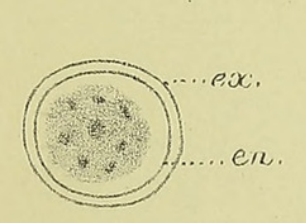

a

l.

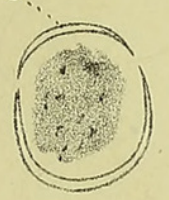

a

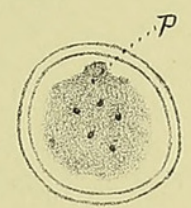

$\mathrm{b}$

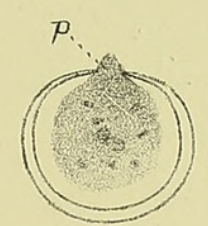

C

17.

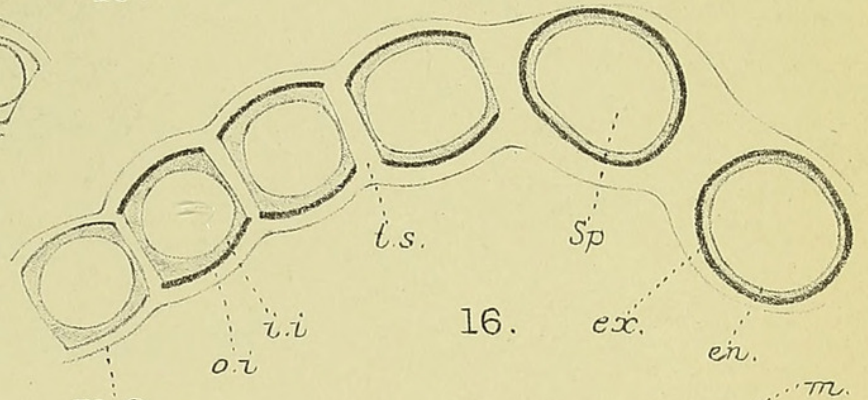

mi.s.
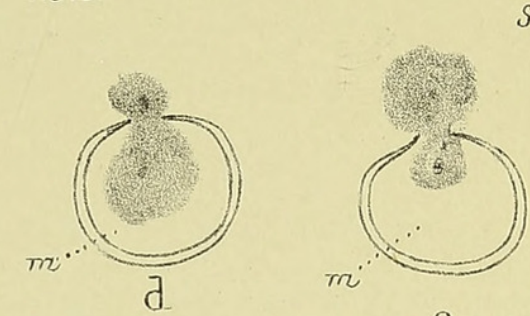

e.

18.
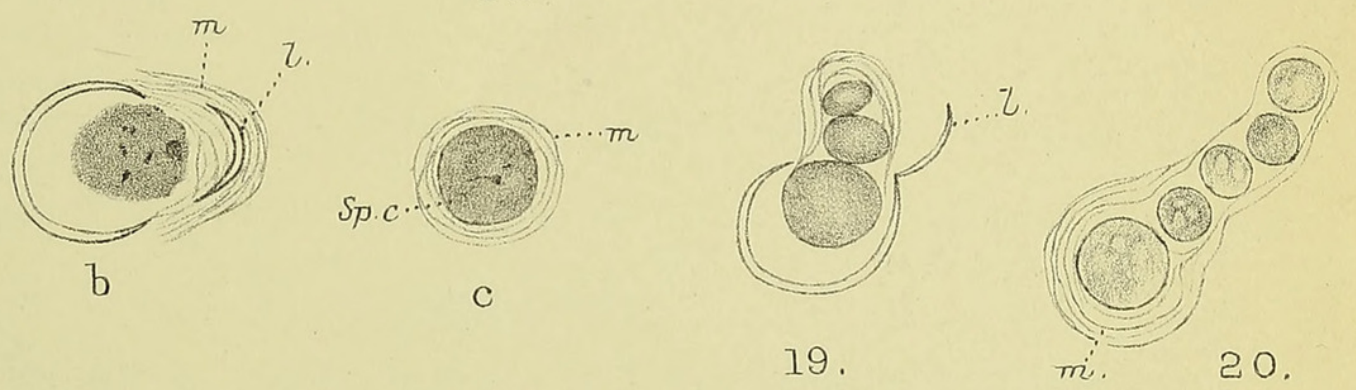

19.

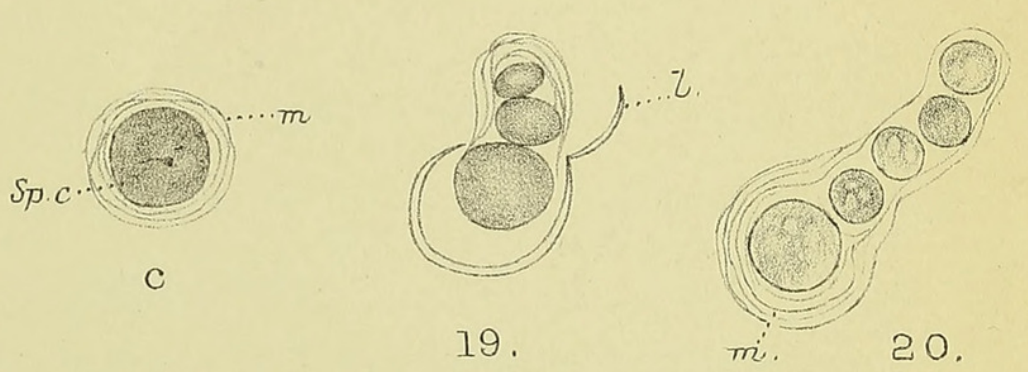

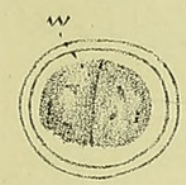

a

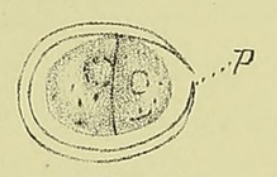

b

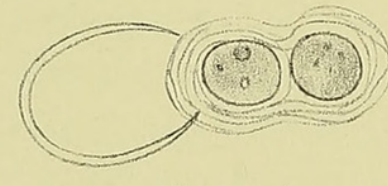

c

21.

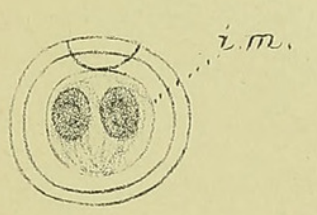

a

23.

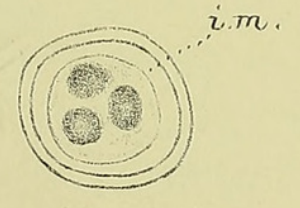

b
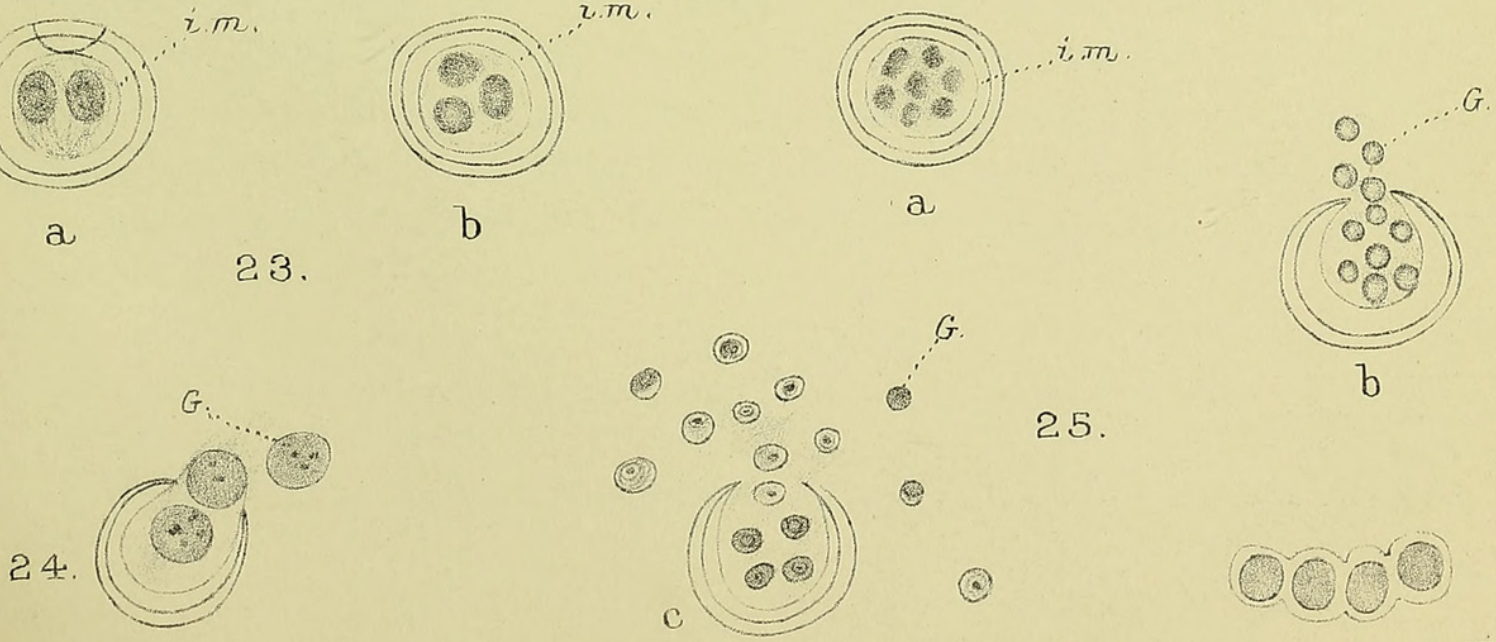

25.

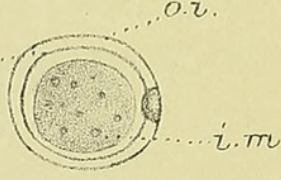

22. 

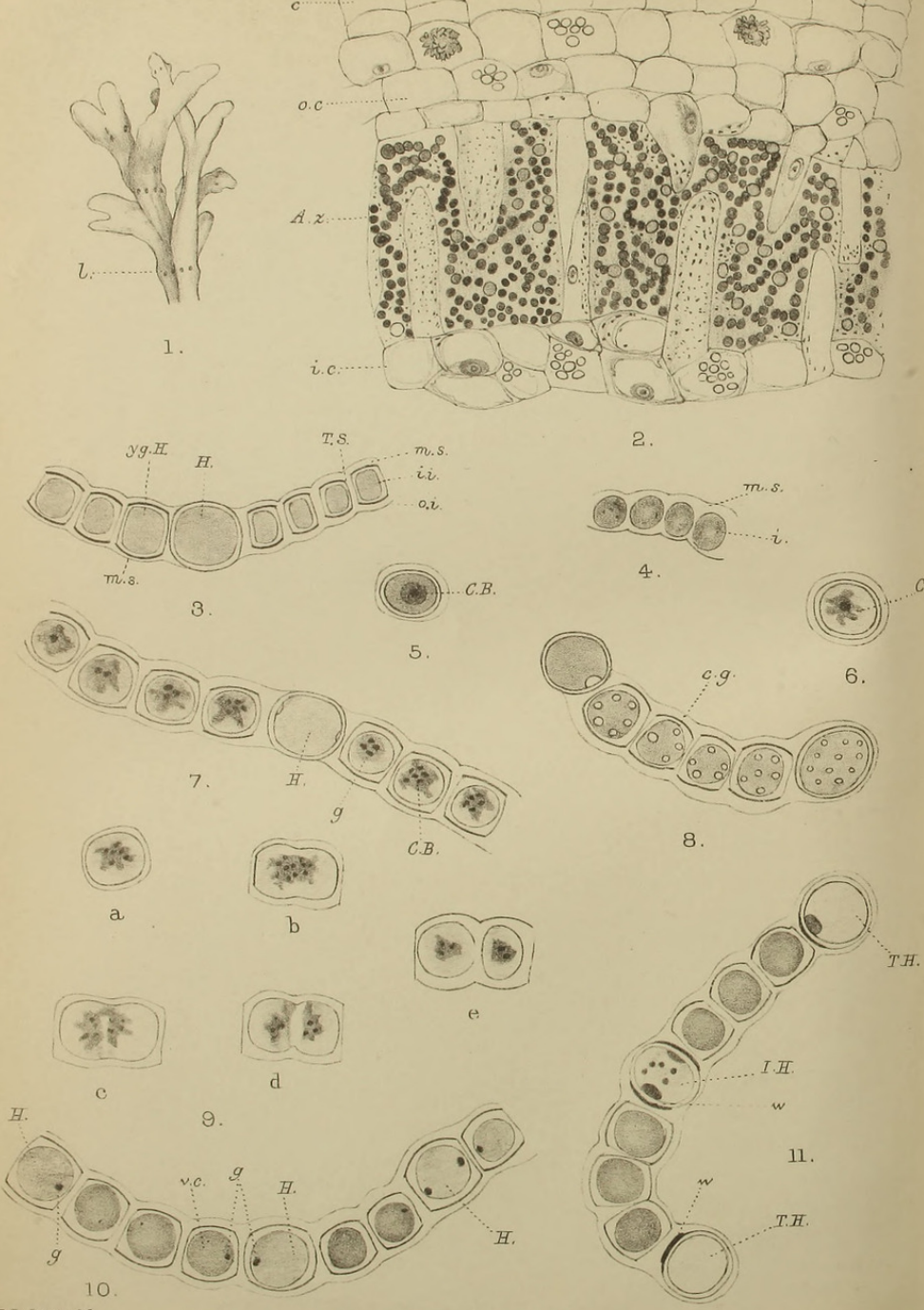
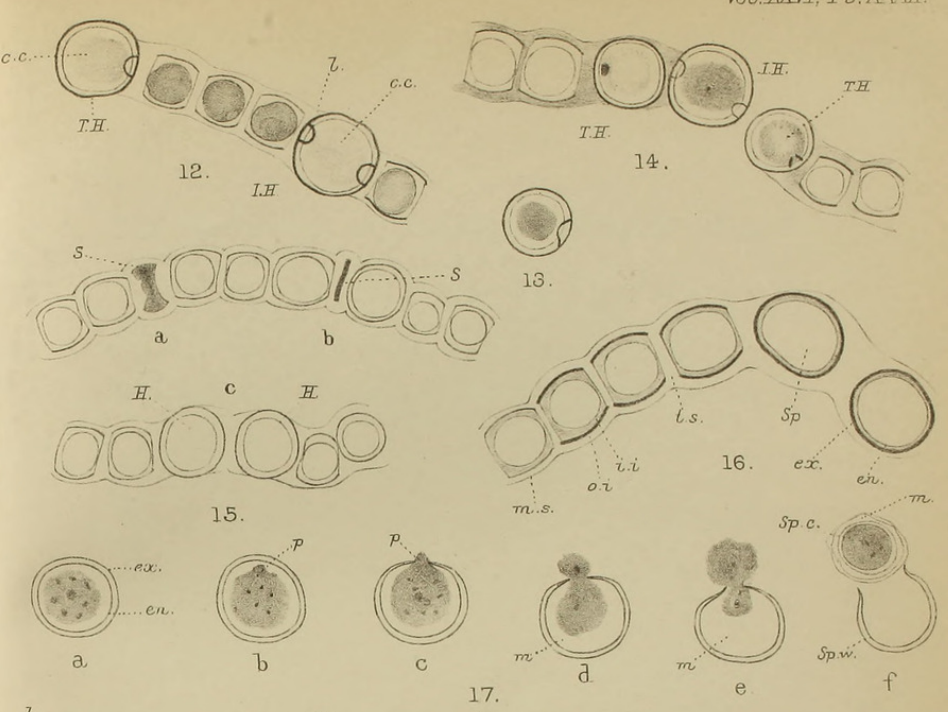

(3)
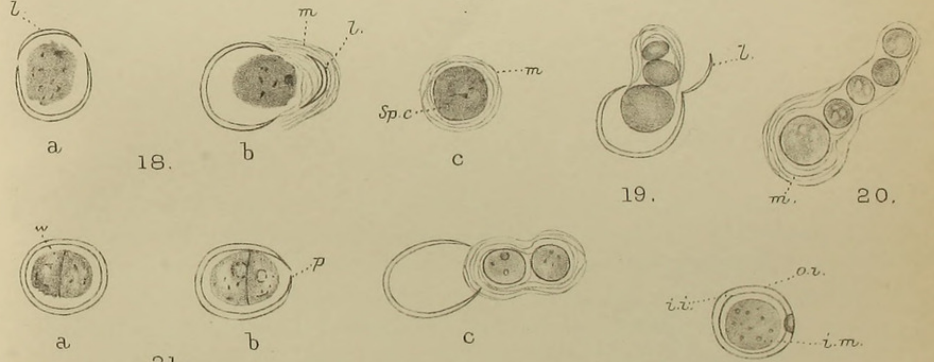

19. 20.
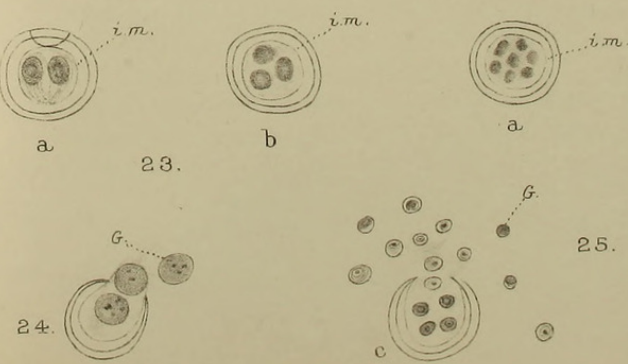

b

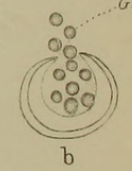

000026 


\section{$2 \mathrm{BHL}$ Biodiversity Heritage Library}

Spratt, Ethel Rose. 1911. "Some observations on the life-history of Anabaena cycadeae." Annals of botany 25, 369-380.

https://doi.org/10.1093/oxfordjournals.aob.a089333.

View This Item Online: https://www.biodiversitylibrary.org/item/236971

DOI: https://doi.org/10.1093/oxfordjournals.aob.a089333

Permalink: https://www.biodiversitylibrary.org/partpdf/319841

\section{Holding Institution}

Smithsonian Libraries

\section{Sponsored by}

Biodiversity Heritage Library

\section{Copyright \& Reuse}

Copyright Status: Not in copyright. The BHL knows of no copyright restrictions on this item.

This document was created from content at the Biodiversity Heritage Library, the world's largest open access digital library for biodiversity literature and archives. Visit BHL at https://www.biodiversitylibrary.org. 